\title{
Studies on the Bacillus sphaericus Larvicidal Activity against Malarial Vector Species in Amazonia
}

\author{
Iléa Brandão Rodrigues/ ${ }^{+}$, Waderli Pedro Tadei, José Manoel C Silva Dias*
}

\author{
Instituto Nacional de Pesquisas da Amazônia, Caixa Postal 478, 69083-000 Manaus, AM, Brasil
}

*CENARGEN - EMBRAPA, Brasília, DF

\begin{abstract}
In this work, bioassays were carried out in laboratory conditions (average temperature $26 \pm 2^{\circ} \mathrm{C}$ ) to test ten strains of Bacillus sphaericus, isolated from Brazilian soils against third instar larvae from anopheline species recorded as malaria vectors in Amazonian - Anopheles nuneztovari and An. darlingi. With the former mosquito, three strains $-S_{2}, S_{20}$ and $S_{46}$ showed relative activity, in 24 and $48 \mathrm{hr}$ exposure to the B. spahericus strains. With the latter only the $S_{2}$ and $S_{20}$ were effective in the $48 \mathrm{hr}$ reading. The studied strains that showed the most adequate response in the Amazonian region were $S_{2}$ and $S_{20}$ showing broader and more efficient results. Therefore, $S_{2}$ was the most effective when the 24 and $48 \mathrm{hr}$ readings were considered, because it showed the greatest relative activity values.
\end{abstract}

Key words: malaria - biological control - anopheline - Bacillus sphaericus

In the Amazonian region there are great malaria transmission areas mainly those with recent disturbance caused by settling, mining camps and some native villages, where a large number of vectors exists. The methodology used for the control of these mosquitoes, in this region, has been based on intradomicilium chemical control, which has not accomplished the same results as observed in other regions in the southern and southeastern parts of the country.

The importance of new technologies in the seeking of intervention strategies, such as for planning and application of preventive measures and vector control in a selective way is being pointed out. The biological control is an important strategy when prioritizing the enviromental question. For malaria in Amazonian endemic areas, the application of this means of attack on immature forms is one of the most relevant methods for winged density control. Therefore, in order to be implemented, bioassays are needed to evaluate the Anopheles species response to the biological control agents.

This work presents the first data obtained on the susceptibility of anopheline larvae, which are pointed out as malaria vectors in Amazonia Anopheles nuneztovari and An. darlingi, to ten strains of Bacillus sphaericus isolated from Brazilian soils.

This project received financial support from Fundo Nacional do Meio Ambiente.

${ }^{+}$Corresponding author. E-mail: brandao@ inpa.gov.br Received 17 November 1997

Accepted 20 April 1998

\section{MATERIALS AND METHODS}

Anopheline females collected in the suburbs of Manaus, State of Amazonas and in the municipal district of Jaciparaná, State of Rondônia, Brazil, were used in bioassays. Mosquitoes were laid to oviposit one by one in the insectary at a temperature of $26 \pm 2^{\circ} \mathrm{C}$, with relative humidity of 80 $90 \%$, and were maintained in the laboratory according to Santos et al. (1981).

Ten strains of B. sphaericus were utilized in this work. They were isolated from soils colected in the following localities: Brasília, Federal District - $\mathrm{S}_{2}, \mathrm{~S}_{46}$; Corumbá, State of Mato Grosso $\mathrm{S}_{7}, \mathrm{~S}_{11}, \mathrm{~S}_{15}, \mathrm{~S}_{17}, \mathrm{~S}_{20}, \mathrm{~S}_{21}$ and $\mathrm{S}_{24}$; Vitória, State of Espírito Santo - $S_{32}$. These were taken from the Microbian Germoplasm Bank of Centro Nacional de Pesquisas de Recursos Genéticos e Biotecnológicos (CENARGEN). All the strains belong to serotype H5a5b (Barjac 1990, Schenkel et al. 1992, Dias 1992). For comparing Brazilian strains, the B. sphaericus strain 2362, the World Health Organization (WHO) standard strain was utilized.

The bioassays were conducted with third instar larvae, with six or seven concentrations of lyophilized bacteria ranging from $0.5 \mathrm{ppb}$ to $50 \mathrm{ppm}$. The lyophilized of each strain was prepared from cultures in a rotating incubator $\left(30 \pm 0.5^{\circ} \mathrm{C}, 200 \mathrm{rpm}\right)$ for $48 \mathrm{hr}$, centrifuged and rinsed with destilled water, frozen and lyophilized from 12 to $15 \mathrm{hr}$. Same as Brazilian isolates, strain 2362 has been grown and prepared for assay in the same way.

Twenty larvae per concentration tested from each Anopheles species were used in one single bioassay. The method used in the observation of mortality and survival of the biossays was the one of Dulmage et al. (1990), with some changes. 
The target population average for lethal concentration $\left(\mathrm{LC}_{50}\right)$ in each period of observation (24 and $48 \mathrm{hr}$ ) was estimated through probits analysis (Finney 1981) using the POLO-PC program. The relative activity (RA) was calculated using $B$. sphaericus 2362 as a standard, acording to the following formula:

$$
\mathrm{RA}=-\frac{\mathrm{LC}_{50} \text { standard }}{\mathrm{LC}_{50} \text { sample }}
$$

The values of RA were calculated for $48 \mathrm{hr}$ results.

\section{RESULTS AND DISCUSSION}

The larvicidal activity of the ten Brazilian strains tested can be evaluated by the association of the $\mathrm{LC}_{50}$ values (Table I) with the RA (Table II). Regarding An. nuneztovari, it is observed that the $S_{2}, S_{20}$ and $S_{46}$ are the most effective with $\mathrm{LC}_{50}$ values between 0.084-0.127 ppm in $48 \mathrm{hr}$ reading. In this last reading, considering $B$. sphaericus 2362 as a standard, the three cited strains showed RA varying from 3.7 to 5.6 times. The RA shows values above four units, except for $\mathrm{S}_{2}$ in the $48 \mathrm{hr}$ reading (Table II). Few strains were effective in the control of An. darlingi, when we associated $\mathrm{LC}_{50}$ to RA. The $\mathrm{S}_{2}, \mathrm{~S}_{20}$ and $\mathrm{S}_{46}$ were again stressed (only in the $48 \mathrm{hr}$ reading) with RA around four and five times.

Figure shows the graphic representation of the dosage response line for the $\mathrm{S}_{2}, \mathrm{~S}_{20}$ and $\mathrm{S}_{46}$ strains to the two species. Figure also shows the values for the $2362 \mathrm{WHO}$ standard strain. It is observed that for An. nuneztovari (Figs 1A, 1B) the $\mathrm{S}_{2}, \mathrm{~S}_{20}$ and $\mathrm{S}_{46}$ strains were more effective than the 2362 . It has also been shown that the linear regression straight lines of the 2362 strain, in both Figs, presents a relatively parallel pattern to the $S_{2}$ and $S_{20}$ straight lines. In An. darlingi (Figs 1C, 1D) the $\mathrm{LC}_{50}$ values of $\mathrm{S}_{2}$ and $\mathrm{S}_{20}$ are close to the 2362 strain, in the $24 \mathrm{hr}$ reading. The $\mathrm{S}_{2}$ is more effective being close to the $S_{20}$ and 2362 values, in 48 $\mathrm{hr}$. The linear regression straight lines of $\mathrm{S}_{2}, \mathrm{~S}_{20}$ and 2362 are divergent in the minor concentration doses (abscissa), for they show zero mortality ( 24 hr) or next to $10 \%\left(48 \mathrm{hr}-\mathrm{S}_{2}\right.$ and $\left.\mathrm{S}_{20}\right)$. There are no studies about biological activity of $B$. sphaericus against anophelines which are important in the Amazonian region. $\mathrm{S}_{2}$ and $\mathrm{S}_{20}$ straight lines cross with the one from 2362 in values near the $\mathrm{LC}_{50}$ from the three strains. The RA data (Table II)
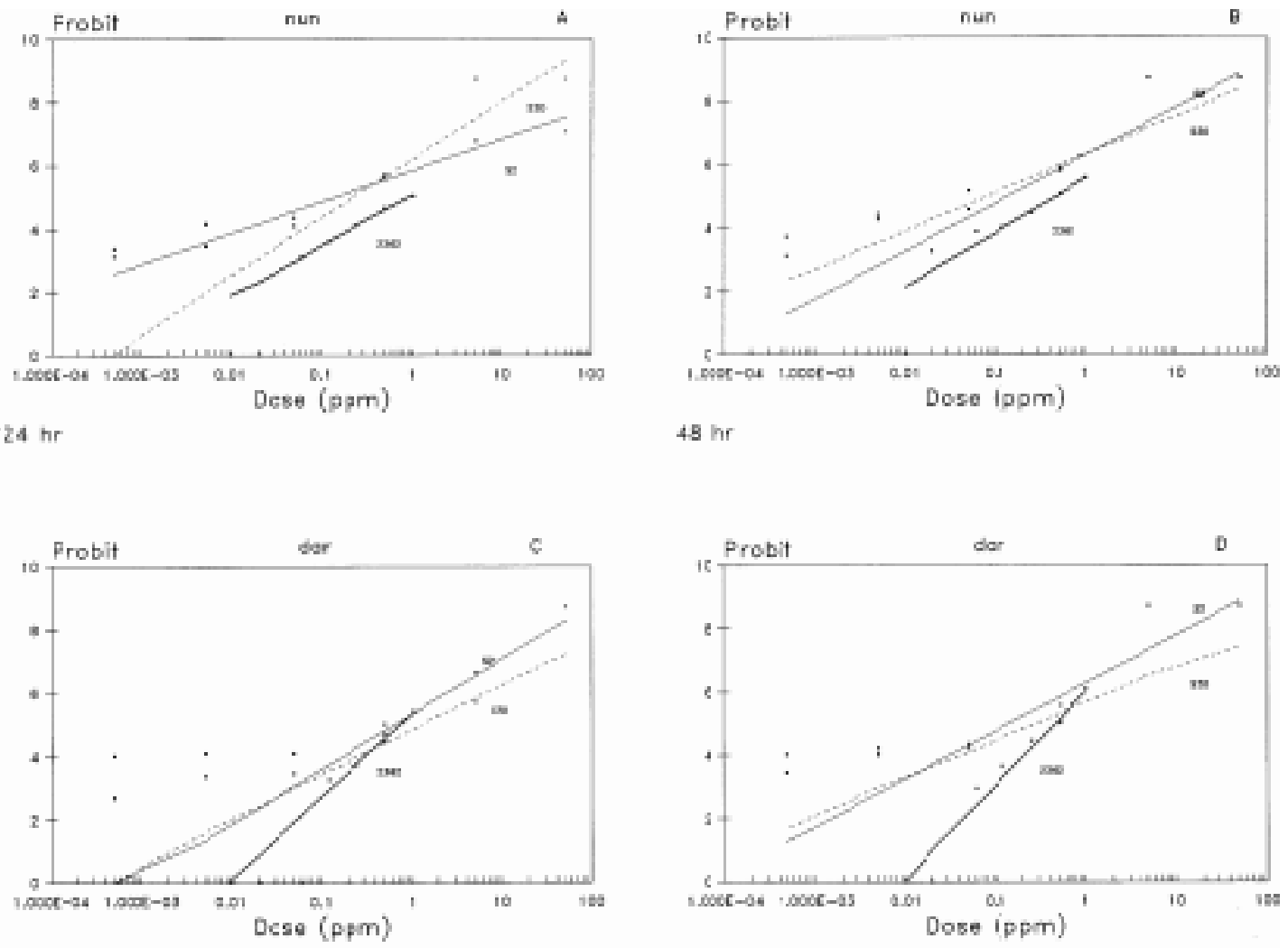

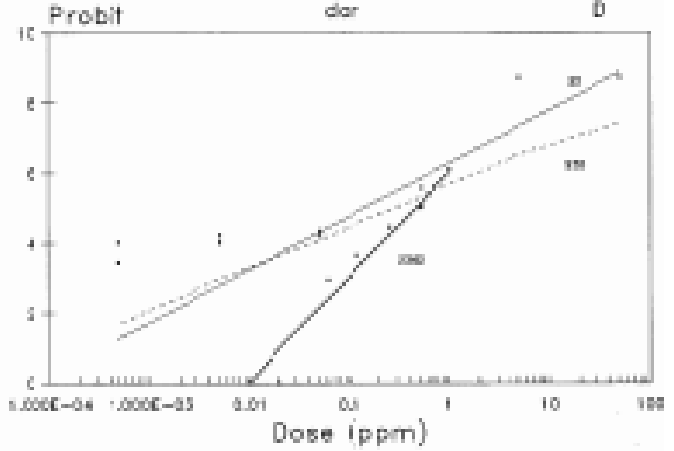

48 $\operatorname{tr}$

Dose response line of Bacillus sphaericus Brazillian strains against third instar larvae Anopheles species. 
TABLE I

Values of the mean lethal concentration $\left(\mathrm{LC}_{50}\right.$, $\left.\mathrm{ppm}\right)$ of Bacillus sphaericus Brazillian strains against Anopheles species

\begin{tabular}{lrrrrr}
\hline & \multicolumn{4}{c}{ Species } \\
\cline { 2 - 3 } Strains & \multicolumn{2}{c}{ An. nuneztovari } & & \multicolumn{2}{c}{ An. darlingi } \\
\cline { 2 - 3 } \cline { 6 - 6 } & $24 \mathrm{hr}$ & $48 \mathrm{hr}$ & & $24 \mathrm{hr}$ & $48 \mathrm{hr}$ \\
\hline $\mathrm{S}_{2}$ & 0,169 & 0,127 & & 1,187 & 0,092 \\
$\mathrm{~S}_{7}$ & 1,519 & 0,783 & & 1,006 & 0,337 \\
$\mathrm{~S}_{11}$ & 0,613 & 0,462 & & 4,740 & 2,592 \\
$\mathrm{~S}_{15}$ & 0,634 & 0,534 & & 0,383 & 0,142 \\
$\mathrm{~S}_{17}$ & 4,253 & 4,229 & & 0,252 & 0,174 \\
$\mathrm{~S}_{20}$ & 0,205 & 0,084 & & 0,493 & 0,097 \\
$\mathrm{~S}_{21}$ & 0,652 & 0,661 & & 1,753 & 0,647 \\
$\mathrm{~S}_{24}$ & 0,466 & 0,239 & & 0,669 & 0,254 \\
$\mathrm{~S}_{32}$ & 260,908 & 273,885 & & 2,572 & 23,012 \\
$\mathrm{~S}_{46}$ & 0,159 & 0,105 & & 1,119 & 0,106 \\
2362 & 0,895 & 0,470 & & 0,735 & 0,457 \\
\hline
\end{tabular}

TABLE II

Relative activity ${ }^{a}$ values of $48 \mathrm{hr}$ readings of Bacillus sphaericus Brazilian strains against Anopheles species

\begin{tabular}{lcc}
\hline & \multicolumn{2}{c}{ Relative activity } \\
\cline { 2 - 3 } Strains & An. nuneztovari & An. darlingi \\
\hline $\mathrm{S}_{2}$ & 3,709 & 4,967 \\
$\mathrm{~S}_{7}$ & 0,601 & 1,356 \\
$\mathrm{~S}_{11}$ & 1,020 & 0,176 \\
$\mathrm{~S}_{15}$ & 1,676 & 3,218 \\
$\mathrm{~S}_{17}$ & 0,111 & 2,626 \\
$\mathrm{~S}_{20}$ & 5,607 & 4,711 \\
$\mathrm{~S}_{21}$ & 0,712 & 0,706 \\
$\mathrm{~S}_{24}$ & 1,971 & 1,799 \\
$\mathrm{~S}_{32}$ & 0,001 & 0,019 \\
$\mathrm{~S}_{46}$ & 4,431 & 4,310 \\
\hline
\end{tabular}

a: standard strain is B. sphaericus 2362.

revealed that the $\mathrm{S}_{2}$ and $\mathrm{S}_{20}$ strains were effective for the two species either at 24 or at $48 \mathrm{hr}$ readings. Considering the other tested strains, in a general way, the RA values were lower than when compared to standard B. sphaericus 2362 strain. Therefore, it is observed that the Brazilian strains that presented a potential for the control of the anopheline immature forms were $\mathrm{S}_{2}, \mathrm{~S}_{20}$ and $\mathrm{S}_{46}$, at 24 or $48 \mathrm{hr}$ readings.

The studies on new strains against anopheline immature forms have been carried out in different parts of the world. Mulla (1986) tested larvicidal activity of different $B$. sphaericus 2362 preparations, and of 1593 and 2297 strains against $A n$. albimanus and An. quadrimaculatus. In relation to the two Anopheles species, an activity variation of mortality rate caused by $B$. sphaericus 2362 was observed An. albimanus was from 8 to 25 times more sensitive than An. quadrimaculatus. Formulations showed different levels of larvicidal activity, according to the 2297 AP and SD strain formulations and to the 1593 Sawdust formulation, which showed high larvicidal activity levels against An. albimanus and low activity against An. quadrimaculatus. Studies with different B. sphaericus strains, distributed into the six serotypes, were made testing An. sthephensi third instar larvae. Comparatively, the average $\mathrm{LC}_{50}$ on An. stephensi larvae were around $10^{-5} \mathrm{FWC}$ dilutions (Thiery \& Barjac 1989).

Other strains from different places in Brazil, that were also isolated at CENARGEN, were used by Schenkel et al. (1992) in bioassays with An. albimanus. These authors tested $\mathrm{S}_{1}, \mathrm{~S}_{2}, \mathrm{~S}_{5}$ and $\mathrm{L}_{2}$ (all isolated from Brasília) against An. stephensi larvae, taking the mortality rate observed with $B$. sphaericus 2362 as a standard. They observed that only $\mathrm{L}_{2}$ did not show larvicidal activity similar to the 2362 isolated strain, against this mosquito species. The $\mathrm{S}_{2}$ strain showed a toxicity that also affects other genera and Anopheles sub-genera. $B$. sphaericus entomopatogenic strain was first reported in a soil sample from Distrito Federal, pointing to $S_{2}$ (Schenkel et al. 1992). Later characterization and biological activity showing that $S_{2}$ is equaly or even more toxic than 2362 for $A n$. albimanus and An. quadrimaculatus. Besides these, $\mathrm{S}_{2}$ was biochemicaly characterized and differenciated from 2362 through lipid gaseous chromagraphy of the cell wall (Vilarinhos 1991).

The continuos isolation of new strains from native ones has indicated that many of these isolates showed a greater larvicidal activity than the 2362 strain.

Concluding, it should be pointed out that in several experiments in which $S_{2}$ was used, against several Anopheles species, this strain showed high larvicidal activity often greater than the standard 2362 strain.

Brazilian strains of $B$. sphaericus show a greater larvicidal activity against Anopheles species, the malarian vectors in Amazonia, in relation to the standard 2362 strain. An. nuneztovari third instar larvae were more susceptible to strains: $\mathrm{S}_{2}$, $\mathrm{S}_{20}$, and $\mathrm{S}_{46}$ in 24 and $48 \mathrm{hr}$ exposure. In An. darlingi only $\mathrm{S}_{2}$ was effective in the two readings. The $\mathrm{S}_{20}$ showed greater activity only in the $48 \mathrm{hr}$ reading. These data revealed that $S_{2}, S_{20}$ and $S_{46}$ strains were potentialy the most adequate for the Amazonian region, against the studied species immature forms. Therefore, $S_{2}$ can be pointed out as the most effective one, for it showed activity in both readings with higher RA values. 


\section{REFERENCES}

Barjac H 1990. Classification of Bacillus sphaericus strains and comparative toxicity to mosquito larvae, p. 228-236. In H Barjac, DJ Sutherland (eds), Bacteriol Control of Mosquitoes \& Black Flies: Biochemistry, Genetics \& Applications of Bacillus thuringiensis israelensis and Bacillus sphaericus, Rutgers University Press, New Brunswick.

Dias JMCS 1992. Produção e utilização de bioinseticida bacteriano. Pesp Agropec Bras 27: 59-76.

Dulamge HT, Yousten AA, Singer S, Lacey LA 1990. Guidelines for Production of Bacillus thuringiensis H-14 and Bacillus sphaericus, UNDP/World Bank/ WHO, Steering Committee to Biological Control of Vetores, Geneva, 59 pp.

Finney DJ 1981. Probit Analysis, 3 ed., S. Chand \& Company Ltd, Ram Nagar, New Delhi, 333 pp.

Marques AC, Gutierrez HC 1994. Combate à malária no Brasil: evolução, situação atual e perspectivas. Rev Soc Bras Med Trop 27 (Supl. III): 91-108.

Mulla MS 1986. Efficacy of the microbial agent Bacillus sphaericus Neide against mosquitoes (Diptera: Culicidae) in southern California. Bull Soc Vector Ecol 11: 247-254.

Rubio-Palis Y 1992. Malaria in the Americas: Ecological/epidemiological paradigms, p. 21. Interregional Meeting on Malaria for the Americas. Pan America Health Organization/World Health Organization, Brasília.
Santos JMM, Contel EPB, Kerr WE 1981. Biologia de Anofelinos Amazônicos. I. Ciclo biológico, postura e estádios larvais de Anopheles darlingi Root, 1926 (Diptera: Culicidae) da Rodovia Manaus/Boa Vista. Acta Amazon 11: 789-797.

Schenkel ROM, Nicolas L, Frachon E, Hamon S 1992. Charaterization and toxicity to mosquito larvae of four Bacillus sphaericus strains isolated from Brazilian soils. Invert Pathol 60: 10-14.

Tadei WP, Santos JMM, Scarpassa VM, Rodrigues IB 1993. Incidência, distribuição e aspectos ecológicos de espécies de Anopheles (Diptera: Culicidae), em regiões naturais e sob impacto ambiental da Amazônia Brasileira, p. 167-196. In EJG Ferreira, GM Santos, ELM Leão, ELM Oliveira (eds), Bases Científicas para Estratégias de Preservação e Desenvolvimento da Amazônia, Vol. 2, Instituto Nacional de Pesquisas da Amazônia, Manaus.

Thiery I, Barjac H 1989. Selection of the most potent Bacillus sphaericus strains based on activity ratios determinet on three mosquito species. Appl Microbiol Biotechnol 31: 577-581.

Vilarinhos PTR 1991. Biological Activity and Biochemical Characterization of a New Isolate of Bacillus sphaericus (Neide) highly toxic to mosquito larvae, MSc Thesis, University of Florida, Flórida, 95 pp.

WHO-World Health Organization 1988. Report on a techinical consultation on research in support of malaria control in the Amazon Basin, WHO,TDR/ FIELDMAL/SC/AMAZ/88.3. 